\title{
Histopathology and the lethal effect of Cry proteins and strains of Bacillus thuringiensis Berliner in Spodoptera frugiperda J.E. Smith Caterpillars (Lepidoptera, Noctuidae)
}

\author{
Knaak, N. ${ }^{\text {a* }}$,Franz, AR. ${ }^{\text {a }}$ Santos, GF. ${ }^{\text {a }}$ and Fiuza, LM. ${ }^{\mathrm{a} b *}$ \\ aLaboratório de Microbiologia, Universidade do Vale do Rio dos Sinos - UNISINOS, \\ Av. Unisinos, 950, CEP 93001-970, São Leopoldo, RS, Brazil \\ ${ }^{b}$ Instituto Riograndese do Arroz Irrigado - IRGA, Cachoeirinha, RS, Brazil \\ *e-mail: fiuza@unisinos.br,neivaknaak@gmail.com \\ Received December 29, 2008 - Accepted April 29, 2009 - Distributed August 31, 2010
}

\begin{abstract}
Among the phytophagous insects which attack crops, the fall armyworm, Spodoptera frugiperda (J.E. Smith, 1797) (Lepidoptera, Noctuidae) is particularly harmful in the initial growth phase of rice plants. As a potential means of controlling this pest, and considering that the entomopathogen Bacillus thuringiensis Berliner demonstrates toxicity due to synthesis of the Cry protein, the present study was undertaken to evaluate this toxic effect of B. thuringiensis thuringiensis 407 ( $\mathrm{pH} 408$ ) and B. thuringiensis kurstaki HD-73 on S. frugiperda. The following method was used. Both bacterial strains were evaluated in vitro in $1^{\text {st }}$ instar $S$. frugiperda caterpillars, by means of histopathological assays. The Cry1 Ab and Cry1Ac proteins, codified by the respective strains of B. thuringiensis, were evaluated in vivo by bioassays of $1^{\text {st }}$ instar $S$. frugiperda caterpillars in order to determine the Mean Lethal Concentration $\left(\mathrm{LC}_{50}\right)$. The results of the histopathological analysis of the midget of $S$. frugiperda caterpillars demonstrate that treatment with the B. thuringiensis thuringiensis strain was more efficient, because the degradations of the microvilosities started 9 hours after treatment application (HAT), while in the B. thuringiensis kurstaki the same effect was noticed only after 12 HAT. Toxicity data of the Cry $1 \mathrm{Ab}$ and Cry1Ac proteins presented for the target-species $\mathrm{LC}_{50}$ levels of 9.29 and $1.79 \mu \mathrm{g} . \mathrm{cm}^{-2}$ respectively. The strains and proteins synthesised by $B$. thuringiensis thuringiensis and $B$. thuringiensis kurstaki are effective in controlling $S$. frugiperda, and may be used to produce new biopesticides or the genes may be utilised in the genetic transformation of Oryza sativa L.
\end{abstract}

Keywords: Bacillus thuringiensis, bioassays, histopathology, Cry proteins, Spodoptera frugiperda.

\section{Histopatologia e efeito letal de cepas e proteínas Cry de Bacillus thuringiensis Berliner para lagartas de Spodoptera frugiperda J.E. Smith (Lepidoptera, Noctuidae)}

\begin{abstract}
Resumo
Entre os insetos fitófagos que atacam as culturas, Spodoptera frugiperda (J.E. Smith, 1797) (Lepidoptera, Noctuidae) destaca-se como uma praga polífaga que causa prejuízos na fase inicial da cultura do arroz. No seu controle, o entomopatógeno Bacillus thuringiensis Berliner revela-se tóxico devido à síntese de proteínas Cry. Nesse contexto, o objetivo deste trabalho foi avaliar a toxicidade das cepas e proteínas Cry de B. thuringiensis thuringiensis 407 (pH 408 ) e B. thuringiensis kurstaki HD-73 sobre S. frugiperda. As duas cepas bacterianas foram avaliadas, in vitro, em lagartas de $1^{\circ}$ instar de $S$. frugiperda, através de ensaios de histopatologia. As proteínas Cry1Ab e Cry1Ac, codificadas pelas respectivas cepas de $B$. thuringiensis, foram avaliadas in vivo, através de bioensaios com lagartas de $1^{\circ}$ instar de S. frugiperda para determinação da Concentração Letal Média $\left(\mathrm{CL}_{50}\right)$. Os resultados da análise histopatológica do intestino médio das lagartas $S$. frugiperda mostram que o tratamento com a cepa $B$. thuringiensis thuringiensis foi mais eficiente e a degradação das microvilosidade iniciou-se 9 horas após a aplicação dos tratamentos (HAT). Para B. thuringiensis kurstaki, o mesmo efeito foi observado, 12 HAT. Os dados de toxicidade das proteínas de Cry1Ab e Cry1Ac revelaram para a espécie-alvo uma $\mathrm{CL}_{50}$ de 9,29 e $1,79 \mu \mathrm{g} . \mathrm{cm}^{-2}$, respectivamente. As cepas e proteínas sintetizadas por B. thuringiensis thuringiensis e B. thuringiensis kurstaki são eficientes no controle de $S$. frugiperda, e poderão ser usadas na produção de novos biopesticidas ou a utilização dos genes na transformação genética de Oryza sativa L.
\end{abstract}

Palavras-chave: Bacillus thuringiensis, bioensaios, histopatologia, proteínas Cry, Spodoptera frugiperda. 


\section{Introduction}

Agricultural production has evolved, and scientific progress has laid the foundation for various technologies leading to increased agricultural production. Despite such progress, insects still destroy cultivated plants, many times jeopardising the production process (Gallo et al., 2002). Attacks by phytophagous pests cause significant decreases in the productivity of corn and irrigated rice crops. Among the phytophagous insects that attack these cultures, Spodoptera frugiperda (J.E. Smith, 1797) (Lepidoptera, Noctuidae) is considered one of the most harmful pests (Grützmacher et al., 2000) because it feeds on the young plants and, in irrigated rice plantations before the crops are flooded, it can reach high population levels and totally destroy the plants (Martins and Botton, 1998).

In the State of Rio Grande do Sul in Brazil, infestation by this pest is a serious concern for the producers who react by using preventative chemical pesticides that may create resistance to the synthetic molecules of the pesticides, and cause various environmental problems. As these environmental problems increase, researchers look for alternative methods of pest control capable of reducing the harmful effects of the chemical products, by rationalising the applications (Carlini and Grossi-de-Sá, 2002).

In the last fifty years, one of the alternatives to biological control that has achieved success in controlling various insect pests on a commercial scale is the use of the entomopathogen Bacillus thuringiensis (Schnepf et al., 1998).

Bacteria of the Bacillus genus have great potential use as biological control agents because they remain viable for long storage periods (Alves, 1998). B. thuringiensis is a Gram-positive bacterium that produces crystal inclusions of proteins during the sporulation made up of insecticidal Cry proteins (Van Rie et al., 1990; Hofmann et al., 1998). These crystals, when ingested by susceptible insects are dissolved under alkaline conditions in the midgut, and then broken into smaller fragments by proteases (Tojo and Aizawa, 1983; Schnepf et al., 1998; Shao et al., 1998; Bravo et al., 2007). Binding occurs due to the association of the activated toxin molecules with specific proteins located in the microvilosities of the epithelial cells in the midgut (Schwartz et al., 1997; Masson et al., 1999; De Maagd et al., 2003). The formation of a pre-pore oligomeric structure facilitates the insertion of the Cry proteins inside the membrane of the columnar cells and is important for the toxicity of the toxin. The formation of the structure has been demonstrated for the toxins, Cry1Aa, Cry1Ab, Cry1Ca, Cry1Da, Cry1Ea, Cry1Fa e Cry3, and the formation of the oligomeric structure of the toxins correlated with that of the pore (Bravo et al., 2007). Subsequently, the pore is formed (Masson et al, 1999) and the ion flux through that pore leads to cell lysis and the consequent death of the susceptible pest organisms (Schnepf et al.,1998; Monnerat and Bravo, 2000). When the toxin dosage fails to kill the insect, its cells are substituted allowing normal feeding to proceed and the recuperation of development of the insect (Spies and Spence, 1995). The midgut of the Lepidoptera is composed of pseudostratified epithelium, formed by three kinds of cells - columnar, globular (Cioffi, 1979) and regenerative -located on the base, between the columnar and the globular cells. These cells demonstrate mitosis activity before each change (Baldwin and Hakim, 1991; Engelhard et al., 1991).

Cry proteins are coded by different genes, whose classification is based on the similarity of aminoacid sequences (Crickmore et al., 1998). More than 350 Cry proteins genes have been cloned and sequenced in recent years from different strains of $B$. thuringiensis (Crickmore et al., 2009). However, the proteins of the Cry 1, Cry 2 and Cry 9 classes (Bravo et al., 1998) demonstrate the broadest insecticidal spectrum against the Lepidoptera order.

Various Cry toxins evaluated in recent studies may be active in S. frugiperda, for example: Buntin (2008), testing transgenic corn, and expressing the Cry1 $\mathrm{Ab}$ and Cry1F proteins of $B$. thuringiensis in S. frugiperda and Helicoverpa zea Boddie, 1850, concluded that, while both reduced the infestation of the tested insects, Cry $1 \mathrm{~F}$ was more efficient - this result was also obtained by Siebert et al. (2008). Lima et al. (2008), utilizing the Cry2Ab protein, found $\mathrm{C} \mathrm{CL}_{50}$ of $3.45 \mu \mathrm{g} \cdot \mathrm{mL}^{-1}$ for larvae of the $2^{\circ}$ ínstar of $S$. frugiperda. Sivasupramaniam et al. (2008), testing transgenic cotton and expressing the Cry1Ac and Cry $2 \mathrm{Ab} 2$ proteins, found that cotton plants expressing Cry1Ac isolation and those expressing both Cry1Ac and Cry2Ab2 were toxic for Heliothis virescens Fabicius, 1777 , and S. frugiperda. The no-choice tests resulted in mortality levels of 20-69\% in S. frugiperda.

In this context, the objective of this work is to assess the toxicity of the strains and Cry proteins of B. thuringiensis thuringiensis 407 ( $\mathrm{pH} 408$ ) and B. thuringiensis kurstaki HD-73 against the $S$. frugiperda armyworm.

\section{Material and Methods}

\subsection{Insects}

Spodoptera frugiperda caterpillars were collected in irrigated rice fields in Cachoeirinha/Rio Grande do Sul, Brazil by the Instituto Riograndense do Arroz - IRGA, in October 2004, and identified by Ms. Jaime Vargas de Oliveira. They were maintained in the laboratory, and fed with Poitout and Bues's diet (Poitout and Bues, 1970). The biological cycle was developed under controlled conditions ( $25^{\circ} \mathrm{C}, 12$-hour photophase and $70 \%$ Relative Humidity), in the Insect Breeding Room, Center 2, at the University of the Vale do Rio do Sinos - UNISINOS.

\subsection{Bacillus thuringiensis}

The B. thuringiensis thuringiensis 407 (pH 408) and B. thuringiensis kurstaki HD-73 strains were provided by the International Entomopathogenic Bacillus Centre, Pasteur Institute, Paris (France). The strains were grown in a standard glycolic media, at $180 \mathrm{rpm}$ and $28{ }^{\circ} \mathrm{C}$, for 48 hours (Debarjac and Lecadet, 1976). Subsequently, the bacterial suspension was centrifuged at $5000 \mathrm{rpm}$, and the cell count was made in a Neubauer Chamber 
with an optical microscope, and in a concentration of $1.10^{10}$ cells. $\mathrm{mL}^{-1}$.

In the preparation of the Cry proteins the cultivation of both strains was realised as previously described until a $90 \%$ cell lyses was obtained. The culture was centrifuged at $5000 \mathrm{rpm}$, at $5{ }^{\circ} \mathrm{C}$, for 15 minutes, and the concentrate obtained was washed with phosphate buffer $\left(0.1 \mathrm{M} \mathrm{NaH}_{2} \mathrm{PO}_{4}\right.$. $\mathrm{H}_{2} \mathrm{O}+0.1 \mathrm{M} \mathrm{NaCl}, \mathrm{pH}$ 6.0). Spore, crystal and cell trace separation was realised by applying the bacterial suspension to a sacarose discontinuous gradient $(67-79 \%)$, that was centrifuged at $9500 \mathrm{rpm}, 5{ }^{\circ} \mathrm{C}$ for one hour. The bands deposited among different concentrations of sacarose were collected, washed with mili-Q water and observed by phase contrast microscopy. Next, proteins were dissolved in a pH 10 phosphate buffer ( $50 \mathrm{mM} \mathrm{Na} \mathrm{CO}_{3}, 10 \mathrm{mM}$ DTT, 5 mM EDTA, 0.1 mM PMSF), as described by Fiuza et al. (1996). The Protein concentration was determined by the Bradford method (Bradford, 1976), and the profile was evaluated in SDS-PAGE, at 10\% (Laemmli, 1970).

\subsection{Histopathology assays}

In the treatments with the strains of $B$. thuringiensis thuringiensis 407 ( $\mathrm{pH} 408$ ) and B. thuringiensis kurstaki HD-73, $100 \mu \mathrm{L}$ of suspensions $\left(10^{10}\right.$ cells. $\left.\mathrm{mL}^{-1}\right)$ were applied on the Poitout and Bues diet surface (Poitout and Bues, 1970), arranged on acrylic mini-plates. In the tests, 30 caterpillars of the $1^{\text {st }}$ instar of $S$. frugiperda were placed individually on the acrylic mini-plates containing the treatments. In the control samples, the test elements were substituted by distilled and sterilised water. Treatments were maintained in an acclimatised chamber $\left(25^{\circ} \mathrm{C}, 12\right.$-hour photophase and $70 \%$ Relative Humidity).

In the histological assessments, the $S$. frugiperda tissues

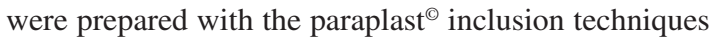
(Brandtzaeg, 1982) and after application of the treatment, the caterpillars were collected in periods of 1, 3, 6, 9, 12 and 24 hours. After fixation in Bouin Hollande sublimate for 24 hours, the tissues were submitted to dehydration in ethanol solutions in an increasing order of graduation, followed by rapid xylol baths and impregnation with paraplast. Longitudinal histological sections were made with a $5 \mu \mathrm{m}$ thickness. To remove the paraplast the slides containing the tissues were passed through xylol and ethanol baths in a decreasing order of graduation. The $S$. frugiperda tissues were stained with Heidenhain's Blue. The slides were assembled with Etellan and glass cover slips. The longitudinal sections of the digestive system of the $S$. frugiperda caterpillars, corresponding to the treatments with the two strains of $B$. thuringiensis and the control, were observed using the comparative histology system and optical microscopy.

\subsection{Bioassays}

Cry $1 \mathrm{Ab}$ and Cry1 Ac proteins were tested in $1^{\text {st }}$ instar caterpillars of S. frugiperda. For each protein, the assays were made up of five protein concentrations $\left(0.06\right.$ at $610 \mu \mathrm{g} . \mathrm{mL}^{-1}$ and 0.1 at $1050 \mu \mathrm{g} . \mathrm{mL}^{-1}$, for Cry $1 \mathrm{Ab}$ and Cry1 Ac, respectively) and a control, representing
6 treatments of 30 insects and 3 repetitions, for a total of 540 insects evaluated by protein. The treatments were applied $(100 \mu \mathrm{L})$ on the Poitout and Bues diet surface (Poitout and Bues, 1970), previously arranged on acrylic mini-plates, where the caterpillars were individualised. In the controls the proteins were substituted by distilled and sterilised water. The test slides were maintained in an acclimatized chamber at $25^{\circ} \mathrm{C}, 70 \%$ Relative Humidity, with a 12 hour photophase. Mortality was evaluated until the seventh day after the application of the treatment, and then corrected using Abbott's formula (Abbott, 1925). The mean lethal concentrations $\left(\mathrm{LC}_{50}\right)$ of each protein (Cry1 Ab and Cry1Ac) at the target species was determined by Probit's Analysis, with the Polo-PC LeOra Software program, 1987 (Haddad, 1998). Data was processed by Variance Analysis and the Tukey test $(p<0.05)$ for comparison of the averages.

\section{Results and Discussion}

In the histopathological analysis of the midgut of S. frugiperda caterpillars treated with the B. thuringiensis thuringiensis 407 ( $\mathrm{pH} 408$ ) strain, structural changes were observed six hours after application of the treatment (HAT), where there were cells in the intestinal lumen and elongation of the microvilosities, as compared to the control. After nine applications of the treatment (HAT) the action was intensified with vacuolisation of the cytoplasm, and the beginning of the degradation of the peritrophic membrane - this was entirely absent after 12 HAT. Treatment with $B$. thuringiensis kurstaki HD-73 strain was similar, except that rupture of the microvilosities (BBMV's) and vacuolisation of the cytoplasm began at 12 HAT.

Comparing the two treatments it can be seen that the B. thuringiensis thuringiensis 407 ( $\mathrm{pH} 408$ ) strain was more active, because the beginning of the degradation of microvilosity occurred at 9 HAT compared with 12 HAT for B. thuringiensis kurstaki HD-73 (Table 1).

Various other works report the cellular changes produced in the midgut of larvae intoxicated with the Cry proteins of B. thuringiensis, such as: an increase in the volume of the epithelium cells, rupture of microvilosities, vacuolisation of the cytoplasm, changes in the organelles of the cytoplasm and cell hypertrophy (Griego et al., 1980; Mathavan et al., 1989; Bravo et al., 1992). Similar changes were observed in intoxications with Cry1Ac and Cry1D in S. frugiperda (Aranda et al., 1996), thus confirming the data reported in this study for the Cry1Ac protein synthesised by the B. thuringiensis kurstaki HD-73 isolate.

Knaak and Fiuza (2005) tested the nuclear polyhedrosis virus of Anticarsia gemmatalis Hübner, 1818, (VPNAg) and $B$. thuringiensis kurstaki HD-1 (Dipel $\left.{ }^{\circledR}\right)$ in $2^{\text {nd }}$ instar caterpillars of A. gemmatalis (Lepidoptera, Noctuidae), and observed that when both entomopathogens are utilised simultaneously they are more efficient, because they caused alterations in the intestinal cells after 6 HAT while when used separately they produced the alteration only after 12 HATs. This data is similar to that obtained in the present study because the treatment with $B$. thuringiensis kurstaki 
Table 1. Histopathology of $1^{\text {st }}$ instar Spodoptera frugiperda (Lepidoptera, Noctuidae) treated with Bacillus thuringiensis thuringiensis 407 (pH 408) (Btt) and Bacillus thuringiensis kurstaki HD-73 (Btk) isolates.

\begin{tabular}{|c|c|c|c|c|c|c|c|c|c|}
\hline \multicolumn{2}{|c|}{ Treatments } & $\begin{array}{l}\text { Changes } \\
\text { in } \\
\text { peritrophic } \\
\text { membrane }\end{array}$ & $\begin{array}{l}\text { BBMVs } \\
\text { changes }\end{array}$ & $\begin{array}{c}\text { Cels./ } \\
\text { intestinal } \\
\text { light } \\
\text { projection }\end{array}$ & $\begin{array}{c}\text { Larger } \\
\text { cell } \\
\text { turgor }\end{array}$ & $\begin{array}{c}\text { Celular } \\
\text { hypertrophy }\end{array}$ & $\begin{array}{c}\text { Cyoplasm } \\
\text { vacuolization }\end{array}$ & $\begin{array}{c}\text { Rupture } \\
\text { of the } \\
\text { peritrophic } \\
\text { membrane }\end{array}$ & $\begin{array}{l}\text { BBMVs } \\
\text { rupture }\end{array}$ \\
\hline \multicolumn{2}{|r|}{ Control } & - & - & - & - & - & - & - & - \\
\hline \multirow{6}{*}{$\mathrm{Btt}$} & 1HAT & - & - & - & - & - & - & - & - \\
\hline & 3HAT & - & - & - & - & - & - & - & - \\
\hline & 6HAT & + & + & + & - & - & - & - & - \\
\hline & 9HAT & + & + & + & + & + & + & + & + \\
\hline & 12HAT & + & + & + & + & + & + & + & + \\
\hline & 24HAT & + & + & + & + & + & + & + & + \\
\hline \multirow{6}{*}{ Btk } & 1HAT & - & - & - & - & - & - & - & - \\
\hline & 3HAT & - & - & - & - & - & - & - & - \\
\hline & 6HAT & + & + & + & - & - & - & - & - \\
\hline & 9HAT & + & + & + & - & - & - & + & - \\
\hline & 12HAT & + & + & + & + & + & + & + & + \\
\hline & 24HAT & + & + & + & + & + & + & + & + \\
\hline
\end{tabular}

(+) Presence of changes in the midgut (-) absence of changes in the midgut, HAT $=$ hours after treatment application, $\mathrm{BBMV}=$ microvillosities

HD-73 also demonstrated alterations in the microvilosities after 12 HATs.

Loeb et al. (2001) tested increasing concentrations of $B$. thuringiensis AA 1-9 and HD-73 toxins and found that they induced reductions related to the total number of cells in the midgut of Heliothis virescens. After two days of exposure at $800 \rho g . \mu \mathrm{L}^{-1}$ de AA $1-9$ e $600 \rho g . \mu \mathrm{L}^{-1}$ de HD-73, the columnar and the globular cells showed a $20 \%$ decrease when compared with the control, thus leading to the conclusion that HD-73 toxin was more efficient than the AA 1-9 toxins. In this paper, S. frugiperda data show that the cytotoxic activity of the above-mentioned strain (B. thuringiensis kurstaki HD-73) is slower than that of B. thuringiensis thuringiensis 407 ( $\mathrm{pH} 408$ ).

Rausel et al. (2000a) observed the vacuolisation of the cytoplasm and rupture of the microvilosities in Lymantria monacha Linnaeus, 1758 caterpillars exposed to Cry1A toxins, and for the Cry1Ac protein, as well as the effects mentioned, found in vitro tests disorganisation of the midgut and hypertrophy of the epithelium cells, which were loosened and ejected into the intestinal lumen. Furthermore, Baines et al. (1997), when testing Cry1A toxins of B. thuringiensis in Lepidoptera, stated that the collapse provoked in the electro-chemical gradient in the midgut epithelium causes the death of the insect, thus confirming the insecticidal activity of this class of Cry proteins against the lepidopteras.

During in vitro tests by Peyronnet et al. (1997) they used the Cry1Aa protein in Lymantria dispar Linnaeus, 1758 , cells to cause a quick and irreversible depolarisation of the membrane, but the same effect was not observed with the Cry1 Ab and Cry1Ac proteins, so that these two must be considered inactive against the Lepidoptera species. On the other hand, Lambert et al. (1996) have shown that the same Cry protein can present different effects for two species of the same insect order - for example, Cry1Ac was very toxic to $H$. virescens, but non-toxic to Heliothis armigera Hübner, 1808. Also, Aranda et al. (1996) suggest that the explanation for the different interactions between $\mathrm{Cry} 1 \mathrm{Ab}$ and Cry1 Ac is that the toxins interact with different receptors in S. frugiperda.

As for the effectiveness of the B. thuringiensis strain in the $S$. frugiperda midgut, the manner in which way the proteins bind to the receptor is relevant (Fiuza, 2004), because, according to Ferre et al. (1991), Lee et al. (1995a) and MacIntosh et al. (1992), it is the key factor of the specificity, toxicity and resistance of the insects to Cry proteins. Considering the two proteins used in this study, one should mention that an amino-peptidase $\mathrm{N}$ of $120 \mathrm{kDA}$, located in the membrane of the intestinal epithelium of the Lepidoptera for Cry1Ac (Knight et al., 1994) and cadherin correspond to the receptor for Cry $1 \mathrm{Ab}$ (Vadlamudi et al., 1993). These epithelium receptors of the midgut of Lepidoptera larvae can be shared by different Cry proteins (Ballester et al., 1999; Martinez-Ramirez et al., 1999), and alterations can make the insects resistant to these toxins (Lee et al., 1995; Schnepf et al., 1998). Estela et al. (2004) have shown that Cry1 Aa, Cry1Ab and Cry1Ac compete for receptor sites on the membrane of the midgut of H. armigera, and that Cry1Ac and Cry $1 \mathrm{Ab}$ use different epitopes to bind to the membrane. Competition experiments have shown that CrylAc and CrylBa share a binding site on the $C$. suppressalis membrane, and that this location is also used as a binding site for CrylAa 
Table 2. Mean Lethal Concentration of Cry1Ab and Cry1Ac proteins of Bacillus thuringiensis to $1^{\text {st }}$ instar Spodoptera frugiperda (Lepidoptera, Noctuidae).

\begin{tabular}{cccc}
\hline Treatments & \multicolumn{3}{c}{ Proteins $\left(\mu \mathbf{g . c m}^{-2}\right)$} \\
\cline { 2 - 4 } & LC $_{\mathbf{5 0}}$ & CI (IL-UL) & $\chi^{\mathbf{2}}$ \\
\hline Cry1Ab protein & 9.29 & $4.34-28.46$ & 1.59 \\
Cry1Ac protein & 1.79 & $0.96-3.76$ & 1.08 \\
\hline
\end{tabular}

*CI = Confidence Interval, estimated at 95\% probability through Probit's Analysis; IL = Inferior Limit; UL = Upper Limit.

(Fiuza et al., 1996). Cry1Ab and Cry1Ac identify the same binding site on Ostrinia nubilalis Hübner, 1796 epithelium effectively competing for the same location (Denolf et al., 1993) and are closely related to each other sharing $84 \%$ of the amino acids (Lee et al., 1995a). This data can also justify the way that $B$. thuringiensis acts in the S. frugiperda midgut.

Aronson et al. (1999), examining the steps required to insert toxins into the membrane, and the possible formation of ionic channels, observed that the oligomerisation chain of the Cry1Ac toxin on the membrane of the H. virescens midgut was longer than that of Manduca sexta Linnaeus, 1763 , and the binding would correspond directly to the toxicity. Furthermore, with reference to the action mode, Zhuang et al. (2002) report that the integrity of lipid pouches is related to the Cry $1 \mathrm{Ab}$ activity and the consequent formation of the pores that lead to the death of the insect. In the $B$. thuringiensis action sequence, fixing the toxin onto the membrane is a necessary step for formation of the pore (Schnepf et al., 1998; Aronson and Shai, 2001).

In this research, data on the toxicity of Cry $1 \mathrm{Ab}$ and Cry1Ac proteins, synthesised by $B$. thuringiensis thuringiensis 407 ( $\mathrm{pH} 408$ ) and B. thuringiensis kurstaki HD-73, respectively, showed a Mean Lethal Concentration $\left(\mathrm{LC}_{50}\right.$ ) of 9.29 and $1.79 \mu \mathrm{g} . \mathrm{cm}^{-2}$ to $1^{\text {st }}$ instar of $S$. frugiperda caterpillars.

The data on $\mathrm{CL}_{50}$ shown in Table 2, and the respective confidence intervals, are regarded as dependable because, according to $\chi^{2}$, the data obtained agrees with Probit's model, and the estimated value of $\chi^{2}$ is smaller than the tabulated value (8.89), and is therefore, not significant.

Praça et al. (2004), selecting B. thuringiensis strains that are effective against $2^{\text {nd }}$ - instar $S$. frugiperda, compared new strains to $B$. thuringiensis kurstaki HD-1 ( $\mathrm{LC}_{50}$ de $0.285 \mu \mathrm{g} . \mathrm{cm}^{-2}$ ), and obtained a $\mathrm{LC}_{50}$ of 0.09 and $0.52 \mu \mathrm{g}$. $\mathrm{cm}^{-2}$, for S234 and S997 respectively, which showed the new S234 strain as the most toxic to $S$. frugiperda. In studies with Cry proteins, Aranda et al. (1996) determined that the $\mathrm{LC}_{50}$ for $S$. frugiperda of Cry $1 \mathrm{Ab}$ and Cry1Ac proteins was higher than $2 \mu \mathrm{g} . \mathrm{cm}^{-2}$, and therefore differ somewhat from the results of this study, wherein the Cry1Ac protein $\left(1.79 \mu \mathrm{g} . \mathrm{cm}^{-2}\right)$ was significantly more toxic to the target species when compared to the Cry1 Ab protein $(9.29 \mu \mathrm{g}$. $\mathrm{cm}^{-2}$ ). Rausell et al. (2000) have reported that when they analysed the larval development of Thaumetapoea pityocampa Denis \& Schiffermuller, 1775 and L. monacha, the Cry1Ab and Cry1Ac toxicity decreased as the insect's age increased, although the loss of activity was more marked for Cry1Ab.

Meng et al. (2003) calculated the $\mathrm{LC}_{50}$ of Cry1 Ac and $\mathrm{Cry} 1 \mathrm{Ab}$ proteins from commercial products of B. thuringiensis for newly-born larvae of Chilo suppressalis (Walker) (Lepidoptera, Pyralidae), which were from 15 to $157 \mathrm{mg}(\mathrm{AI}) / \mathrm{L}$ and 2 to $34 \mathrm{mg}(\mathrm{AI}) / \mathrm{L}$, respectively. On the other hand, however, Fiuza et al. (1996) when testing $B$. thuringiensis Cry proteins in $2^{\text {nd }}$ instar $C$. suppressalis caterpillars, observed that the $\mathrm{LC}_{50}$ for Cry1Ac was $2.24 \mu \mathrm{g} . \mathrm{cm}^{-2}$.

The present study concludes that the Cry1Ac protein was more toxic to the target insect than Cry1 Ab. Waquil et al. (2002a, b) verified that corn cultures expressing the Cry1 Ab and Cry1 proteins were moderately resistant to $S$. frugiperda reducing both the survival and the development of the larvae. In laboratory and field studies with eight corn hybrids evaluated for resistance to $S$. frugiperda and Diatraea grandiosella Dyar, 1911, Williams et al. (1997) concluded that the expression of the Cry1Ab toxin produced characteristics of high resistance to the $S$. frugiperda and practically conferred immunity of the D. grandiosella. In tests utilising cotton expressing the Cry1Ac protein, Sivasupramaniam et al. (2008) found mortality rates between $20-69 \%$ for caterpillars of the $2^{\text {nd }}$ instar of S. frugiperda.

These results confirm that strains and proteins synthesised by $B$. thuringiensis thuringiensis 407 ( $\mathrm{pH} 408)$ and B. thuringiensis kurstaki HD-73 are efficient in controlling S. frugiperda, and that Cry1Ac protein was the most effective. Furthermore, they can be used to make new biopesticides or the genes utilised to genetically transform the Oryza sativa L. in order to resist the $S$. frugiperda armyworm.

\section{References}

ABBOTT, WSA., 1925. Method of computing the effectiveness insecticides. Journal of Economic Entomology, vol. 18, no. 1, p. 265-267.

ALVES, SB., 1998. Controle microbiano de insetos. 2 ed. Piracicaba: FEALQ. 1163 p.

ARANDA E., SANCHEZ, J., PEFERON, M., GUERECA, L. and BRAVO, A., 1996. Interactions of Bacillus thuringiensis Crystal Proteins with the Midgut Epithelial Cells of Spodoptera frugiperda (Lepidoptera: Noctuidae). Journal of Invertebrate Pathology, vol. 68, no. 3, p. 203-212. 
ARONSON, AI. and SHAI, Y., 2001. Why Bacillus thuringiensis insecticidal toxins are so effective: unique features of their mode of action. FEMS Microbiology Letters, vol. 195, no. 1, p. 1-8.

ARONSON, AI., GENG, C. and WU, L., 1999. Aggregation of Bacillus thuringiensis Cry1A toxins upon binding to target insect larval midgut vesicles. Applied and Environmental Microbiology, vol. 65 , no. 6 , p. 2503-2507.

BAINES, D., SCHWARTZ, JL., SOHI, S., DEDES, J. and PANG, A., 1997. Comparison of the response of midgut epithelial cells and cell lines from lepidopteran larvae to CryIA toxins from Bacillus thuringiensis. Journal of Insect Physiology, vol. 43, no. 9 , p. 823-831.

BALDWIN, KM. and HAKIM, RS., 1991. Growth and differentiation of the larval midgut epithelium during molting. Tissue and Cell, vol. 23 , no. 3 , p. $411-422$

BALLESTER, V., GRANERO, F., TABASHNIK, BT., MALVAR, T. and FERRÉ, J., 1999. Integrative model for binding of Bacillus thuringiensis in susceptible and resistant larvae of the diamondback moth. Applied and Environmental Microbiology, vol. 65, no. 4, p. 1413-1419.

BRADFORD, MM., 1976. A rapid and sensitive method for quantification of microgram quantities of protein utilizing the principle of protein-dye binding. Analytical Biochemistry, vol. 72, no. 1 , p. $248-254$.

BRANDTZAEG, P., 1982. Tissue preparation methods for immunocytochemistry. In BULLOCK, G. and PETRUZ, P. (Eds.). Techniques in immunocytochemistry. London: Academic Press. p. 49-51.

BRAVO, A., GILL, SS. and SOBERÓN, M., 2007. Mode of action of Bacillus thuringiensis Cry and Cyt toxins and their potential for insect control. Toxicon, vol. 49, no. 4, p. 423-435.

BRAVO, A., HENDRICKX, K., JANSENS, S. and PEFEROEN, M., 1992. Immunocytochemical analysis of specific binding of Bacillus thuringiensis insecticidal crystal proteins to lepidopteran and coleopteran midgut membranes. Journal of Invertebrate Pathology, vol. 60, no. 3, p. 247-253.

BRAVO, A., SARABIA, S., LOPEZ, L., ONTIVEROS, H., ABARCA, C., ORTIZ, A., ORTIZ, M., LINA, L., VILLALOBOS, FJ., PENA, G., NUNES-VALDEZ, ME., SOBERÓN, M. and QUINTERO, R., 1998. Characterization of cry Genes in a Mexican Bacillus thuringiensis Strain Collection. Applied and Environmental Microbiology, vol. 64, no. 12, p. 4965-4972.

BUNTIN, GD., 2008. Corn expressing Cry1 Ab or Cry1F endotoxin for fall armyworm and corn earworm (Lepidoptera:Noctuidae) management in field corn for grain production. Florida Entomologistm, vol. 91, no. 4, p. 523-530.

CARLINI, CR. and GROSSI-DE-SÁ, MF., 2002. Plant toxic proteins with insecticidal properties. A review on their potentialities as bioinsecticides. Toxicon, vol. 40, no. 11, p. 1515-1539.

CIOFFI, M., 1979. The morphology d fine structure of larval midgut of a moth (Manduca sexta) relation to active ion transport. Tissue and Cell, vol. 11, no. 3, p. 467-479.

CRICKMORE, N., ZEIGLER, DR., FEITELSON, J., SCHNEPF, E., VAN RIE, J., LERECLUS, D., BAUM, J. and DEAN, DH., 1998. Revision of the literature for the Bacillus thuringiensis pesticidal crystal proteins. Microbiology and Molecular Biology, vol. 62 , no. 3 , p. $807-813$
CRICKMORE, N., ZEIGLER, DR., SCHNEPF, E., VAN RIE, J., LERECLUS, D., BAUM, J., BRAVO, A. and DEAN, DH., 2009. Bacillus thuringiensis toxin nomenclature. Available from: $<$ http://www.biols.susx.ac.uk/Home/Neil_Crickmore/Bt/>. Access in: $12 / 03 / 2009$.

DE MAAGDA, RA., BRAVO, A., BERRY, C., CRICKMORE, N. and SCHNEPF, E., 2003. Structure, diversity, and evolution of protein toxins from spore-forming entomopathogenic bacteria. Annual Review of Genetics, vol. 37, p. 409-433.

DEBARJAC, H. and LECADET, MM., 1976. Dosage biochimique d'exotoxine thermostable de Bacillus thuringiensis d'après Inhibition d'ARN-polymerases bacteriennes. Comptes Rendus de. L'academie des Sciences, vol. 282, no. 1, p. 2119-2122.

DENOLF, P., JANSENS, S., PEFEROEN, M., DEGHEELE, D. and VAN RIE, J., 1993. Two different Bacillus thuringiensis deltaendotoxin receptors in the midgut brush border membrane of the European corn borer, Ostrinia nubilalis (Hübner) (Lepidoptera: Pyralidae). Applied and Environmental Microbiology, vol. 59, no. 6 , p. $1828-1837$.

ENGELHARD, EK., KEDDIE, BA. and VOLKMAN, LE., 1991. Isolation of third, fourth and fifth instar larval midgut epithelia of the moth, Trichoplusia ni. Tissue and Cell, vol. 23, no. 6 , p. 917-928.

ESTELA, A., ESCRICHE, B. and FERRE, J., 2004. Interaction of Bacillus thuringiensis toxins with larval midgut binding sites of Helicoverpa armigera (Lepidoptera: Noctuidae). Applied and Environmental Microbiology, vol. 70, no. 3, p. 1378-84.

FERRE, J., REAL, MD., VAN RIE, J., JANSENS, S. and PEFEROEN, M., 1991. Resistance to the Bacillus thuringiensis bioinsecticide in a field population of Plutella xylostella is due to a change in a midgut membrane receptor. Proceedings of the National Academy of Sciences, vol. 88, no. 12, p. 5119-5123.

FIUZA, LM., 2004. Receptores de Bacillus thuringiensis em insetos. Biotecnologia Ciência e Desenvolvimento, no. 32, p. 84-89.

FIUZA, LM., NIELSEN-LEROUX, C., GOZÉ, R., FRUTOS, R. and CHARLES, JF., 1996. Binding of Bacillus thuringiensis Cry1 toxins to the midgut brush bordes membrane vesicles of Chilo suppressalis (Lepidoptera: Pyralidae): Evidence of Shared binding sites. Applied and Environmental Microbiology, vol. 62, no. 1 , p. 1544-1549.

GALLO, D., NAKANO, O., SILVEIRA NETO, S., CARVALHO, RPL., BAPTISTA, GC., BERTI FILHO, E., PARRA, JRP., ZUCCHI, RA., ALVES, SB., VENDRAMIN, JD., MARCHINI, LC., LOPES, JRS. and OMOTO, C., 2002. Manual de Entomologia Agrícola. São Paulo: CERES. 531 p.

GRIEGO, VM., FANCHER, LJ. and SPENCE, KD., 1980. Scanning electron microscopy of the disruption of tobacco horn worm, Manduca sexta, midgut by Bacillus thuringiensis endotoxin. Journal of Invertebrate Pathology, vol. 35, no. 2, p. 186-189.

HADDAD, ML., 1998. Utilização do Polo-PC para análise de Probit. In: ALVES, SB. Controle Microbiano de Insetos. Piracicaba: FEALQ. p. 999-1013.

HOFMANN, C., VANDERBRUGGEN, H., HÖFTE, H., VANRIE, J., JANSENS, S. and VAN MELLAERT, H., 1998. Specificity of Bacillus thuringiensis $\delta$-endotoxins is correlated with the presence of high affinity binding site in the brush border membrane of target insect midgut. Proceedings of the National Academy of Sciences, vol. 85, no. 21, p. 7844-7848. 
KNAAK, N. and FIUZA, LM., 2005. Histopathology of Anticarsia gemmatalis Hübner (Lepidoptera; Noctuidae) treated with Nucleopolyhedrovirus and Bacillus thuringiensis serovar kurstaki. Brazilian Journal of Microbiology, vol. 36, no. 2, p. 195-199.

KNIGHT, PJK., CRICKMORE, N. and ELLAR, DJ., 1994. The receptor for Bacillus thuringiensis Cry1Ac delta-endotoxin in the brush border membrane of the lepidopteran Manduca Sexta is aminopeptidade N. Molecular Microbiology, vol. 11, no. 3, p. $429-436$.

LAEMMLI, UK., 1970. Smaller sample vols are better. If using large vols make the stack gel bigger. Nature, vol. 227, p. 680-685.

LAMBERT, B., BUYSSE, L., DECOCK, C., JANSENS, S., PIENS, C., SAEY, B., SEURINCK, J., AUDENHOVE, KV., VAN RIE, J., VLIET, AV. and PEFEROEN, MA., 1996. Bacillus thuringiensis insecticidal crystal protein with a high activity against members of the family Noctuidae. Applied and Environmental Microbiology, vol. 62 , no. 8 , p. 80-86.

LEE, MK., RAJAMOHAN, F., GOULD, F. and DEAN, DH., 1995a. Resistance to Bacillus thuringiensis CryIA delta-endotoxins in a laboratory-selected Heliothis virescens strain is related to receptor alteration. Applied and Environmental Microbiology, vol. 61 , no. 11 , p. $3836-3842$.

LEE, MK., YOUNG, BA. and DEAN, DH., 1995. Domain III exchanges of Bacillus thuringiensis CryIA toxins affect binding to different gypsy moth midgut receptors. Biochem Biophys Res Commun, vol. 216, no. 1, p. 306-312.

LIMA, GMS., AGUIAR, SIT., CORREA, RFT., MARTINS, ES., GOMES, ACM., NAGATA, T., DE-SOUZA, MT., MONERAT, RG. and RIBEIRO, BM., 2008. Cry2A toxins from Bacillus thuringiensis expressed in insect cells are toxic to two lepidopteran insects. World Journal of Microbiology e Biotechnology, vol. 24, no. 12 , p. 2941-2948.

LOEB, MJ., MARTIN, PAW., HAKIM, RS., GOTO, S. and TAKEDA, M., 2001. Regeneration of cultured midgut cells after exposure to sublethal doses of toxin from two strains of Bacillus thuringiensis. Journal of insect Physiology, vol. 47, no. 6, p. 599-606.

MACINTOSH, SC., STONE, TB., JOKERSTAR, RS. and FUCHS, RL., 1992. Binding of Bacillus thuringiensis proteins to a laboratoryselected line of Heliothis virescens. Proceedings of the National Academy of Sciences, vol. 88, no. 1, p. 8930-8933.

MARTINEZ-RAMIREZ, AC., GOULD, F. and FERRÉ, J., 1999. Histopathological effects and growth reduction in a suscetible and a resistant strain of Heliothis virescens (Lepidoptera: Noctuidae) caused by sublethal doses of pure Cry1A crystal proteins from Bacillus thuringiensis. Biocontrol Science and Technology, vol. 9, no. 2, p. 239-246.

MARTINS, JFS. and BOTTON, M., 1998. Controle de insetos da cultura do arroz. In PESKE, ST., NEDEL, JL. and BARROS, ACSA. (Eds.). Produção de arroz irrigado. Pelotas: UFPEL, p. 273-300.

MASSON, L., TABASHNIK, BE., LIU, YB. and SCHWARTZ, JL., 1999. Helix 4 of the Bacillus thuringiensis Cry1Aa toxin lines the lumen of the ion channel. Journal of Biological Chemistry, vol. 274 , no. 45 , p. $31996-32000$.

MATHAVAN, S., SUDHA, PM. and PECHIMUTHU, SM., 1989. Effect of Bacillus thuringiensis on the midgut cells of Bombyx mori larvae: A histopathological and histochemical study. Journal of Invertebrate Pathology, vol. 53, no. 2, p. 217-227.
MENG, F., WU, K., GAO, X., PENG, Y. and GUO, Y., 2003. Geographic variation in susceptibility of Chilo suppressalis (Lepidoptera: Pyralidae) to Bacillus thuringiensis toxins in China. Journal of Economic Entomology, vol. 96, no. 6, p. 1838-1842.

MONNERAT, RG. and BRAVO, A., 2000. Proteínas bioinseticidas produzindas pela bactéria Bacillus thuringiensis modo de ação e resistência. In MELO, IS. and AZEVEDO, JL. (Eds.). Controle biológico. Jaguariúna, SP: Editora do MMA. p. 163-200.

PEYRONNET, O., VACHON, V., BROUSSEAU, R., BAINES, D., SCHWARTZ, JL. and LAPRADE, R., 1997. Effect of Bacillus thuringiensis toxins on the membrane potential of lepidopteran insect midgut cells. Applied and Environmental Microbiology, vol. 63 , no. 5 , p. 1679-1684.

POITOUT, S. and BUES, R., 1970. Élevage de plusieurs espéces de Lépidopteres Noctuidae sur milieu artificiel riche et surmilieu simplifié. Annales de Zoologie Ecologie Animale, vol. 2, no. 1, p. 79-91.

PRAÇA, LB., BATISTA, AC., MARTINS, ES., SIQUEIRA, CB., DIAS, DGS., GOMES, ACMM., FALCÃO, R. and MONNERAT, RG., 2004. Estirpes de Bacillus thuringiensis efetivas contra insetos das ordens lepidoptera, coleoptera e diptera. Pesquisa Agropecuária Brasileira, vol. 39, no. 1, p. 11-16.

RAUSELL, C., DECKER, N., GARCIA-ROBLES, I., ESCRICHE, B., VAN KERKHOVE, E., REAL, MD. and MARTÍNEZRAMÍREZ, AC., 2000a. Effect of Bacillus thuringiensis toxins on the midgut of the nun moth Lymantria monacha. Journal of Invertebrate Pathology, vol. 75, no. 4, p. 288-291.

RAUSELL, C., MARTÍNEZ-RAMÍREZ, AC., GARCÍA-ROBLES, I. and REAL, MD., 2000b. A binding site for Bacillus thuringiensis Cry1 Ab toxin is lost during larval development in two forest pests. Applied and Environmental Microbiology, vol. 66, no. 4, p. $1553-1558$.

RÜTZMACHER, AD., MARTINS, JFS. and CUNHA, US., 2000. Insetos-pragas das culturas do milho e sorgo no agroecossistema de várzea. In PARFITT, JMB. Produção de milho e sorgo em várzea. Pelotas: Embrapa Clima Temperado, p. 87-102.

SCHNEPF, E., CRICKMORE, N., VAN RIE, J., LERECLUS, D., BAUM, J., FEITELSON, J., ZEIGLER, DR. and DEAN, DH., 1998. Bacillus thuringiensis and its pesticide crystal proteins. Microbiology and Molecular Biology Reviews, vol. 62, no. 3, p. 775-806.

SCHWARTZ, JL., JUTEAU, M., GROCHULSKI, P., CYGLER, M., PREFONTAINE, G., BROUSSEAU, R. and MASSON, L., 1997. Restriction of intramolecular movements within the Cry1 Aa toxin molecule of Bacillus thuringiensis through disulfide bond engineering. FEBS Letter, vol. 410, no. 2, p. 397-402.

SHAO, Z., CUI, Y., YI, H., JI, J. and YU, Z., 1998. Processing of delta-endotoxin of Bacillus thuringiensis subsp. Kurstaki HD-1 in Heliothis armigera midgut juice and the effect of proteases inhibitors. Journal of Invertebrate Pathology, vol. 72, no. 12, p. 73-81.

SIEBERT, MW., BABOCK, JM., NOLTING, S., SANTOS, AC., ADAMCZYK, JJ., NEESE, PA., KING, JE., JENKINS, JN., MCCARTY, J., LORENZ, GM., FROMME, DD. and LASSITER, RB., 2008. Eficacy of Cry1F insecticidal protein in maize and cotton for control of fall armyworm (LEPIDOPTERA: NOCTUIDAE). Florida Entomologist, vol. 91, no. 4, p. 555-565.

SIVASUPRAMANIAM, S., MOAR, WJ., RUSCHKE, LG., OSBORN, JÁ., JIANG, C., SEBAUGH, JL., BROWN, GR., 
SHAPPLEY, ZW., OPPENHUIZEN, MR., MULLINS, JW. and GRRENPLATE, JT., 2008. Toxicity and characterization of cotton expressing Bacillus thuringiensis Cry1 Ac and Cry2Ab2 proteins for control of lepidopteran pests. Journal of Ecnomic Entomology, vol. 101, no. 2, p. 546-554

SPIES, AF. and SPENCE, KD., 1995. Effect sublethal Bacillus thuringiensis crystal endotoxin treatment on the larval midgut of a moth, Manduca sexta. Tissue and Cell, vol. 17, no. 3, p. 394-397.

TOJO, A. and AIZAWA, K., 1983. Dissolution and degradation of Bacillus thuringiensis $\delta$ endotoxin by gut juice protease of the silkworm Bombyx mori. Applied and Environmental Microbiology, vol. 45 , no. 3 , p. $576-580$

VADLAMUDI, R., JI, T. and BULLA, L., 1993. A specific bindind protein from Manduca sexta for the insecticidal toxin of Bacillus thuringiensis subsp. Berliner. Journal Biological Chemistry, vol. 268, no. 17, p. 12334-12340.

VAN RIE, J., JANSEN, S., HÖFTE, H., DEGHEELED, D. and VAN MELLAERT, H., 1990. Receptors on the brush border membrane of the insect midgut as determinants of the specificity of Bacillus thuringiensis $\delta$-endotoxins. Applied and Environmental Microbiology, vol. 56, no. 5, p. 1378-1385.

WAQUIL, JM., VILLELA, FMF. and FOSTER, JE., 2002a. Resistência do milho (Zea mays L.) transgênico (Bt) à lagartadocartucho, Spodoptera frugiperda (Smith) (Lepidoptera: Noctuidae). Revista Brasileira de Milho e Sorgo, vol. 1, no. 3, p. 1-11.

WAQUIL, JM., VILLELA, FMF., SIEGFRIED, BD. and FOSTER, JE., 2002b. Atividade Biológica das toxinas do Bt, Cry1 Ab e cry1F em, Spodoptera frugiperda (Smith) (Lepidoptera: Noctuidae). Revista Brasileira de Milho e Sorgo, vol. 3, no. 2, p. 161-171.

WILLIAMS, WP., BUCKLEY, PM., SAGERS, JB. and HANTEN, JA., 1997. Evaluation of transgenic corn southwestern corn borer. Crop Science, vol. 37, p. 957-962.

ZHUANG, M., OLTEAN, DI., GÓMEZ, I., PULLIKUTH, AK., SOBERÓN, M., BRAVO, A. and GILL, SS., 2002. Heliothis virescens and Manduca sexta Lipid Rafts Are Involved in Cry1A Toxin Binding to the Midgut Epithelium and Subsequent Pore Formation. Journal Biological Chemistry, vol. 277, no. 16, p. 13863-13872. 